\title{
EMPOWERING ENTREPRENEURSHIP IN FEMALE RUN ICT ENTERPRISES: A STUDY IN KERLA
}

\author{
Rashmi M, Lekshmi V Nair \\ Senior Research Fellow, Department of Humanities, Indian Institute of Space Science and Technology, \\ Trivandrum, Kerala, India \\ rikshan@gmail.com
}

Associate Professor, Department of Humanities, Indian Institute of Space Science and Technology, Trivandrum, Kerala, India Ivnair@gmail.com

\section{ABSTRACT}

The Kudumbashree project from Kerala (a state in the southern part of India) has been a much discussed case for the community of practitioners, policy makers, researchers working on technology, empowerment and development. It is built around three pillars of economic, social and women's empowerment. Its formation was the culmination of a process of community mobilization taken up by the State Government. But this article is focusing on the inclusion of gender in policies relating to information and communication technology with the aim of empowering women as users and producers of this technology. The prominent part of this investigation is the case study of Kudumbashree ICT enterprises in the State of Kerala to understand the factors that resulted in the working of these enterprises. Data were collected from Northern part of Kerala. Focus group discussions and interviews were the method employed to gather information.

\section{Indexing terms/Keywords}

Women employment, ICT (Information and Communication Technology), Kudumbashree, Kerala

\section{Academic Discipline And Sub-Disciplines}

Sociology

\section{SUBJECT CLASSIFICATION}

Gender studies

\section{TYPE (METHOD/APPROACH)}

Qualitative approach

Methods - Interviews, focus group discussions

\section{Council for Innovative Research}

\section{Peer Review Research Publishing System}

Journal: Journal of Social Sciences Research

Vol .7, No.2

jssreditor.cir@gmail.com

www.issronline.com 


\section{INTRODUCTION}

The whole world is in the midst of transformation, the transformation is multidimensional: technological, social, economic, political and cultural. The adoption and rapid diffusion of Information and Communication Technologies (ICT) has been the most radical change of recent decades (Chadha \& Kapoor, 2012). The penetration of information and communication technologies offers great opportunities as more users are getting connected. Hundreds of billions of dollars are spent on ICTs, reflecting a powerful global belief in the transformatory nature of these technologies (Nath, 2001). In the 1990s the entire planet was organized around telecommunicated networks of computers at the heart of information systems and communication processes. The entire realm of human activity depends on the power of information, in a sequence of technological innovation that accelerates its pace by month (Castells, 1999). Development of new software has led in the progression of knowledge gathering and easy computing which in turn creates wealth much faster than any previous generation. Literatures on ICT focus on internet as a medium addressing the gender issues in the developing countries (see also Hafkin and Huyer, 2007; Gurumurthy, 2004). ICTs are increasingly promoted as a key solution for comprehensive development, poverty eradication and the empowerment of historically disadvantaged groups, such as women and minorities in the Global South (Hafkin \& Huyer, 2006; International Telecommunication Union, 2005; Huyer and Mitter, 2003; UNCTAD, 2002; Hafkin and Taggert, 2001; Bhatnagar and Schware, 2000; Heeks, 1999). Business sectors have also enhanced with "software" and "hardware" divisions including businesses such as virtual auction houses, virtual trading for traditional goods, and product-specific or sector-specific portal sites focussing on key niche markets (Martin and Wright, 2005). One key expectation is that internet based business can provide new opportunities for underprivileged or underrepresented. While there is recognition of the potential of ICT as a tool for the promotion of gender equality and the empowerment of women, a "gender divide" has also been identified, reflected in the lower numbers of women accessing and using ICT compared with men (Dalal, 2006).

The Declaration of Agreement in Support of Girls and Women in information and communication technology, introduced at the United Nations World Summit on the Information Society in Tunis, Tunisia on November 16, 2005, stresses that "ICT allows women increased participation in political, social, and economic arenas and supports empowerment for themselves, their families, and their communities." In recent years, therefore, development agencies, such as the World Bank and the Canadian International Development Research Centre (IDRC) have substantially increased funding for ICT projects that specifically aim to empower women, such as e-commerce, e-government, business development and networking projects. Women have increasingly proven to be active and enthusiastic participants in a large variety of ICT enabled projects, such as computer training and data entry facilities, call centres, billing, computer repair work, and eenabled businesses (Hafkin and Huyer, 2006). Many e-commerce projects have become famous in the global market due to their ability to exploit and use the potentials and skills of women at least in the initial stage. The Georgetown-initiated cottage industry, Tortas Peru, the India Shop, Women Entrepreneurs and Handicrafts producers in Bhutan are examples of (at least, initially) successful e-commerce projects. Projects like those by the Delhi based Datamation Foundation, the Information village project in Pondicherry, India and the Grameen Phone Project in Bangladesh serve as models of the potential of the ICT based projects (Maier and Reichert, 2008).

Arising from this growing use of ICTs in developing countries have come a series of studies and findings. Some have been largely optimistic and gender-neutral, seeing the contribution that ICTs can make, for example, to economic development generally or to poverty alleviation specifically (Cecchini, 2002; Kenny, 2002). In recent years special emphasis has been given to the significance, relevance and inclusion of gender issues in the policies concerned with information and communication technologies in developing countries. Such assessments highlighted the importance of integrating gender equality considerations in such policies (Walby, 2000). However, there is a view that the labor component of the ICT labor process that involves lower-value-added jobs (data entry, accounting, book-keeping services) may be production-friendly for the relatively better-off among the poor, but moving up demands at higher levels of skills may be rare among poorer women (ILO, 2001). India gives a significant priority to ICTs both on the production side (as seen, for instance, in the development of its software industry) and on the consumption side (with significant investments in e-government applications, and attempts to push ICTs out into rural areas) (Heeks, 1996; Bhatnagar and Schware, 2000). Application of ICTs has taken place through a variety of different models; for example, from pure market to pure state, and from genderblind to gender-focused (Singall and Rogers, 2001). Spurred on by this, many governments in the individual Indian states have initiated micro reforms to attract more investment in the ICT sector to their respective regions.

The Government of Kerala state (GOK) in South India is no exception and it has developed policies that emphasize ICTs as an engine for industrial growth and employment. First written in 1998 and followed by numerous iterations (one in 2001, one in 2007, and a draft of a new document in 2011), the Kerala IT policy agenda lays out the goals of establishing "Kerala as a leading IT destination...[and] significantly enhance direct and indirect employment creation in the IT sector" through the growth of the ICT sector, transforming Kerala into a knowledge society (2001). More specifically, the goals of the IT policy include, but are not limited to, building the necessary technological infrastructure to create an environment favorable to ICT development; enhancing the necessary human capital required to both produce and use new technologies through education and skill building; and establishing Kerala as an IT industry destination by attracting investments from within and outside the region (Nair and Prasad 2002).The state's ICT policy in this domain articulates a three-fold strategy: (1) establishment of a vibrant ICT industry; (2) building up a robust infrastructure; and (3) up gradation of the quality of human resources (Government of Kerala, 2003). Kerala has also caught on to India's "software boom" (Dayasindhu \& Pradeep, 2003), while on the other hand, Kerala has also played host to a number of innovative state interventions in ICTs, including Kudumbashree, a women-led poverty reduction programme that has made use of ICTs to enable the development of ICT-based enterprises run by cooperatives of poor women. "Akshaya" project was also well known for its mass acceptance but later it transformed into a service provider deviating from its core objective of e-literacy. But still a major portion of women are unemployed. The female work participation rate is also low (21.54 in 2011 census). 
In the past, to generate employment among women, the state extended training and education schemes, promoted women-preferred industries, set up industrial cooperatives, and so on. An experiment was tried out by the Kerala State Electronics Development Corporation (KELTRON), which undertook to promote ancillary industries for the assembling of radios by women's cooperatives for a fee. A detailed study of the scheme revealed that the economic viability of the units was weak as most of the units incurred heavy losses. The units enjoyed only restricted autonomy with regard to prices, delivery of supplies and collection of assembled radios controlled by the parent firm (Pillai and Shanta, 2011). This contributed to erratic production and poor work organization (Sen and Gulati, 1987). Another major initiative at the governmental level was the implementation of the Women's Industries Programme (WIP) aimed at providing employment opportunities to poor women. The programme has resulted in the proliferation of tiny units in low technology areas such as spices, curry masala production and readymade garments. However, the infrastructure and supports for procurement of raw materials, marketing and credit have been inadequate, resulting in very high levels of sickness and closure (Pillai and Shanta, 1998). Numerous factors can impact the success of an ICT based project. Many papers have addressed the gender perspectives related to this topic and there are case studies examining the impact of ICT on the empowerment of women, but the present study focusses on the Kudumbashree IT enterprise which is a government supported entity. The paper will be discussing the major works and associated factors responsible for the functioning of this IT enterprise for women. The present article is focussing on the government intervention, societal support, performance and the networks formed due to the working pattern of these women in ICT enterprises. The required data was collected from government organisations and from Kudumbashree IT enterprises situated in the northern part of Kerala, mainly from five districts which are Kozhikode, Malappuram, Kannur, Wayanad and Kasargode.

\section{KUDUMBASHREE MISSION}

Its formation was the culmination of a process of community mobilization taken up by the Government of Kerala. This started with the community led poverty identification in Alappuzha Municipality in the early nineties followed by a district level effort in Malappuram district in 1994. The decentralization process initiated in 1996 gave a fillip to the process of strengthening women's participation in governance structures. The Kudumbashree Mission was launched in 1998, to create a State wide base of community organizations of women that would work in tandem with the local self governments for poverty eradication and women's empowerment. By 2004, the Kudumbashree Community Organisation network had been established in all Local Self Governments. The need was to rejuvenate the mission and the network to enable them to respond to the changes in the environment more effectively and prepare them to consolidate the gains made. Hence, initiatives for women's empowerment, micro-finance operations, micro enterprise promotion and community action constituted the core activities of Kudumbashree carried out through organizations of women below the poverty line (BPL). These enterprises are all owned, managed and operated by women from such families. Micro enterprise promotion is the prime thrust of the Community Development's Model for Urban Poverty Alleviation. However, these enterprises are more suited to women with lower levels of education (Pillai and Shanta, 2011).

\section{METHODOLOGY}

Various information such as demand and supply of work, structure of support and working conditions etc. was obtained through focus group discussions and interviews of IT enterprise members and officials who have played a key role in the formation of Kudumbashree ICT enterprises. These enterprises are scattered all over the State. Through the data obtained from Kudumbashree office there are over 63 units situated in 14 districts of Kerala as on 2014. Units were selected from five districts of northern Kerala which includes Kozhikode, Malappuram, Kannur, Wayanad and Kasargode. Below is the list of units from the five districts.

Table 1. List of Kudumbahsree ICT enterprises in north Kerala

\begin{tabular}{|c|c|c|}
\hline S. NO & DISTRICT & NO. OF UNITS \\
\hline 1 & Kasargode & 2 \\
\hline 2 & Kannur & 7 \\
\hline 3 & Kozhikode & 3 \\
\hline 4 & Wayanad & 2 \\
\hline 5 & Malappuram & 6 \\
\hline
\end{tabular}

All the 20 units were covered for the purpose of the study and around 92 active members were interviewed. All of them have more than ten years of experience in the field of data entry which indicates that they were present from the beginning of the ICT enterprises. Analysis of the regional spread shows that most of them were situated in urban regions than in rural areas since the programme was initiated in urban areas. Regarding capital investment, each unit possessed around ten computers and two printers. All of them possessed internet as well as telephone connection. On an average, each unit was given a subsidy of US $\$ 1999.52$. In addition, these units took loans with the help of Kudumbashree. The average loan came to around US\$4638.89 (more than twice the subsidy amount). As far as their own contribution was concerned, only a few units reported it. Based on the available data, on an average this would come to about US\$159.96 per unit. Thus, an initial investment of around US\$6798.37 was undertaken in each unit. Each Kudumbashree ICT enterprise started with 10 women. Marriage, lack of permanent income, job opportunity in other sectors and family issues made some members to drop out from these units. On an average, dropouts were around five. Currently in most of the enterprises the average 
strength is five members. Depending on the work load other women were employed as and when required. It ranged from 40 in one unit to a minimum of four in another.The study provides some insights on the sources and type of work. Out of 20 units, 18 units did data entry jobs where as the rest did IT training and hardware jobs. All of them found work on their own as they faced lack in sources of work provided by the Kudumbashree State Office.

\section{KUDUMBAHSREE ICT ENTERPRISES}

ICT microenterprises initiatives are the first among the Kudumbashree activities. They mainly intend to eradicate poverty and empower women through self help groups. In the context of the new innovative organizational structure, success depends on the ability to transform technical learning into opportunities (Pillai and Shanta, 2011). If four or more from a set of nine criteria apply, families are treated as poor or at high risk of poverty by Kudumbashree.

The criteria are:

1. Lack of a proper dwelling;

2. Inaccessibility of safe drinking water;

3. Inaccessibility of sanitary latrines;

4. Not having more than one earning member;

5. Eating less than two meals a day;

6. Presence of children below the age of five;

7. Presence of illiterate adult members;

8. Presence of an alcoholic/drug addict;

9. Socially disadvantaged status.

These IT enterprises are majority-owned or majority-managed by women. In a study (Duncombe et. al, 2005) these IT enterprises were categorised as three main types of ICT-based enterprise:

- Those producing ICTS as an enterprise output: enterprises that produce hardware, software and telecommunications products.

- Those using ICTs as a primary, processing technology: enterprises that provide data entry services, ICT-based business services, software customisation, ICT-based distance learning, etc.

- Those providing other ICT-related support activities: enterprises that provide computer training, consultancy and other services.

These are entities with a business focus having interest in sales, business and perhaps making profit. The data entry micro-enterprise set up as part of the Kudumbashree initiative at Trivandrum, the capital of Kerala State was the first of its kind with members of various self-help groups with basic skills were selected to form the first ever women's group enterprise in data entry, aided with a series of training programs in data entry, software integration, marketing and accounting. The initiative had a budget of US\$6445 raised through a bank loan, members' contributions and a small subsidy. The initial client was the Employee Provident Fund Department for the digitisation of personnel records. For the initial 18 months of operation the unit functioned in the corporation office before moving to a rented building. The unit repaid all its initial loans after three years of operation.

IT@School, a project of Department of General Education, Government of Kerala, setup in 2001, to foster the IT education in schools and which on a longer term would facilitate ICT enabled education in the state led to the formation of another set of Kudumbashree IT enterprises which focussed on IT Training to high school students, and some short-term vacation computer courses to general public. Following an initiative by the local council to set up a hardware assembly enterprise to meet growing demand for PCs, in the year 2003 Kudumbashree organised a group of women from lowincome families to form this enterprise. The prime function of such unit is hardware assembly, installation, service and sales for local councils, schools, banks etc. Financial support was given through a bank loan, and local council subsidy, to set up basic infrastructure and to purchase equipment. Further IT training - in areas such as assembly, installation and maintenance - was provided by a local centre, along with assistance from a marketing company for hardware purchases. The micro-enterprise has also been given enterprise-related training through a Performance Improvements Programme (PIP) (Duncombe et al, 2005).

\section{FINDINGS}

\section{Government and Institutional Support}

This part focusses on the business/work training provided by the government, or the institutional support delivered to the Kudumbashree IT enterprise members along with the initial help offered to them. Interview, focus group discussion were the methods used to get information under this topic. All of them positively responded to this enquiry. It was found that 90 percent of them were a part of their respective Kudumbashree IT unit from the initial stage itself. Either members of the 'Ayalkootam'(Neighborhood group) or their educated daughters with minimum educational qualification of $12^{\text {th }}$ standard were allowed to be a member of this venture. They were then sent for training continued by a test. During the beginning stage, the Kudumabashree officials provided all sorts of support to them ranging from initial training like EDP (Electronic Data Processing) workshop, technical, management, business practices, negotiation techniques, marketing support etc. Data entry, data processing and DTP works are some of the major projects handled by them. This shows the attention received by the Kudumbashree micro enterprises during initiation. It again demonstrates that with the world, the Government of Kerala hopes to reduce the gender inequalities and finds ICT project interventions at the micro level to the designing of macro level gender sensitized policies (Jorge, 2002). An executive committee member's meeting is held 
every month and a general meeting ones every year. The learning from these trainings become important only when they are transformed into performance as learning is of little value to organizations unless it is transferred in some way to performance (Holton et.al, 1997). Learning is an internal behavior, whereas performance is usually a more external.

During the initial stage, works were given by the headquarters itself and all the necessary data like the required software CDs, technical training and contact details were provided. It is clear that the instrumental and the informational support from the officials have helped these micro enterprises to flourish upto some extent. On the basis of the conceptual evaluation model of training proposed by Holton (1996) on individual performance it was found that there are three primary outcomes of training intervention: learning, individual performance, and organizational results which clearly proves the above described finding. If the first two factors are obtained then the result will be better leading to productive organizational outcome. As part of monitoring, evaluation and corrective action a state level consortium of IT units called 'Unnathi' to boost the entrepreneurial acumen of women in the IT sector was formed. All the respondents spoke on the consortium saying that it focuses on the upgrade of IT infrastructure and skills development in addition to facilitating access to expert assistance for the units and it also aims at creating jobs for women in the IT sector, developing new welfare schemes in the fields of education and health as well as boosting collaboration with the IT industry at large.

90 percent of the members said that the training and the institutional supports offered to them also focused on creating a sense of unity and harmony amongst them which they found as another reason for their sustenance. The state of cohesion that group members share also puts light on Emile Durkheim's concept of solidarity. Solidarity is rooted in the configuration of relationships linking the members of a group to one another (Fireman and Gamson, 1979). The members represent cohesion and integration due to the homogeneity of these individuals as they feel connected through similar work, educational and religious training, and lifestyle. Although individuals perform different tasks and often have different values and interest, the order and very solidarity of their association depends on their reliance on each other to perform their specified tasks. Solidarity gives rise to social cohesion and depends upon an awareness of and identification with a collectivity (Hunt and Benford, 2004). The confluence of the activities done by the group members leads to micromobilisation which in turn creates collective identity amongst them.

\section{Performance}

Through the field visits it was found that these members do not maintain a proper record of their transactions. A proper mechanism was not structured to check these matters which made them irresponsible. Hence, there was failure in the systematic maintenance of records on the volume of business handled by them. The study revealed that around 50 percent of the units do not have a proper record that could be used as a reference material. The working environment of more than 60 percent of these units was not found to be systematic and professional. The reason identified was that some of the members went to work in panchayaths, hospitals and other Government institutes which hindered their presence together in the unit. As part of "Unnathi", a State-level consortium of IT units formed in 2012 to boost the entrepreneurial acumen of women in the IT sector paved way for these units to function on their own as complete support from the head office was withdrawn. The issues examined under this topic include business input-output and wage levels. The consortium focussed on upgradation of IT infrastructure and skills development in addition to facilitating access to expert assistance for the units and aimed at creating jobs for women in the IT sector but these women were highly dissatisfied with the inefficient functioning of the consortium experienced by them. It has to be noted that most of the units took loans and all of them ensured the repayment of these loans. This is indicative of the fact that all of them received enough work to cover their debts. The average wage of each member was found to be around US $\$ 40.96$ per month which also deferred based on the volume of work. Loan repayment behavior can be an indicator of the financial condition of these units. 50 percent of the units spoke on the financial instability they faced due to lack of proper support from higher officials. A study of Pillai and Shanta (2011) revealed in their study the sales of these units showing that actual output (19 percent) when compared to the potential per PC (81 percent) was very less. The reason for the steady increase in the income and employment of certain units can be related to their social and economic cohesion. These women even demonstrated high standards of leadership and unity. It was also found that these units have emphasized quality improvement through better use of technology, upgrading of skills and good business networking with local companies, influential individuals and consultants. Another factor which helped these enterprises was logistical advantage. Such units also happened to be located in places where there was scope for getting work orders from sources other than Kudumbashree. The units also developed business strategies for expanding their customer base (Pillai and Shanta, 2011). This was evident in case of Kudumbashree IT enterprises of Kozhikode district. Whereas, in case of Wayanad district, a steep decrease in the number and volume of works was found as it is located at a geographically remote area. Several factors seem to have contributed to the failure of this unit, one being insufficient liquidity to tide over the delay in payment to their staff. In the time of crisis, the units were forced to borrow from moneylenders. Not only did they not try for outside work to resolve the problem, there were also internal conflicts among members. Poor managerial skills, lack of motivation and good leadership can be reason for their decline. The prime cause of failure can also be the subsequent drop-out of members. Accumulation of property as assets also contributes to the performance of these units because if the units perform better, they become financially more secure. 91 percent of the families held land and among the women members around 80 percent of them had acquired land of their own along with assets like house. 3 percent of them live in rented houses which limit them from raising resources for their welfare. The introduction of poor women to the ICT sector seems to have addressed both the social and economic digital divide; the Kudumbashree rendering financial, technical, and managerial assistance and training in both hardware and software (Pillai and Shanta, 2011).

\section{Societal Uphold}

It refers to the support from the community elders, officials and their "significant others". Interview, focus group discussion was used to collect data. All of them said that they received a lot of support in the form of providing infrastructure, tools, and training practices from the officials. Local bodies were hand in hand with the Kerala Government to jointly launch this 
poverty eradication project. This thrust from the government side can also be the reason for the reduction in gender disparity in the usage of ICT. It was observed in a study by Prasad and Sreedevi (2007) that contrary to the opinion (or rather misconception) of the common people of Kerala and the political leadership, the officials tried to tap the potentials of ICT for poverty eradication and employment generation. 95 percent of them came to know about this project through the neighborhood groups. Such organized and systematic effort from both the sides of women and the officials can also be the reason for the success of this project. Looking at the study by Nath (2001), he argued that women over time have learned the advantages offered by ICT and its potential in opening up windows to the outside world. This has put them in a greater control over the activities performed by them laying the foundation for entrepreneurship development. As a backup they also require immediate care from their family as well. 95 percent members were married and had children. Amongst them 60 percent of them have either their mother or their mother in law to help them in their household activities showing the acceptance they get in their home as employed women. This proves the balance of work and family life experienced by these women entrepreneurs, seen to still be a key aspect for women developing successful businesses (Martin, 2003). The findings of Castells (2010) can also be looked in as he focused on the degendering of social institutions where women's communes, and the spaces of freedom of sexual identity, project themselves into society at large by undermining patriarchalism, and by reconstructing the family on a new, egalitarian basis that implies the degendering of social institutions, in opposition to patriarchal capitalism and to the patriarchal state. This is also a proof of the fact that now women (rural and urban) do not support the division of labour followed during the times of their mothers and grandmothers. Castells (2001) has argued that more women have conquered their autonomy, and the new generations of women can no longer relate to the conditions under which their mothers and grandmothers used to live, the more feminism diversifies and transforms gender relations by shifting from emancipation to liberation, ultimately dissolving gender as a cultural category and a material institution that uses biological differences to construct the sexual division of labor.

The role of ICTs in empowering these women to become entrepreneurs was seen as crucial. They all saw the growth of technologies as providing new opportunities for them to become entrepreneurs and to run and manage their business. Empowerment of women would mean equipping women to be economically independent, self-reliant, have positive esteem to enable them to face any difficult situation and they should be able to participate in development activities. The empowered women should be able to participate in the process of decision making (Hazarika, 2011). Whitmore (1988) defines empowerment as an interactive process through which people experience personal and social change, enabling them to take action to achieve influence over the organizations and institutions which affect their lives and the communities in which they live. Keiffer's (1984) work on personal empowerment is one of the only major empirical studies which examines personal empowerment as a process. He labels empowerment as a developmental process which includes four stages: entry, advancement, incorporation, and commitment. The entry stage appears to be motivated by the participant's experience of some event or condition threatening to the self or family, what Keiffer refers to as an act of 'provocation'. In the advancement stage, there are three major aspects which are important to continuing the empowerment process: a mentoring relationship; supportive peer relationships with a collective organization; and the development of a more critical understanding of social and political relations. The central focus of the third stage appears to be the development of a growing political consciousness. Commitment is the final stage - one in which the participants apply the new participatory competence to ever expanding areas of their lives. 90 percent of them experienced a lot of change in their attitude and the behavior from their family members. Now they were more confident, know their desires and recognized their capability of achieving objectives. This observation explains that potentials of ICT include the capacity to neutralize gender distinctions as in digitized sectors, women as professionals have experienced new opportunities and they may fight for greater equality with men in these economic sectors. But they do so largely within the confines of existing hierarchies of economic power. Also, a generalized beneficial effect of social support could occur because large social networks provide persons with regular positive experiences and a set of stable, socially rewarded roles in the community. This kind of support could be related to overall well-being because it provides positive affect, a sense of predictability and stability in one's life situation, and recognition of self-worth. Integration in a social network may also help one to avoid negative experiences (e.g., economic or legal problems) (Cohen and Wills, 1985). Also as these women became economically independent, the resistance towards their job got reduced. The power developed by them may be the outcome of their economic independence. Marx's comments and debates on technology had shown that one's relationship to science and technology becomes ever more symbolic of one's relationship to power (Wendling, 2009). A very major problem identified by them was the lack of attention they could give to childcare and household work. Sometimes it had become difficult for them to balance their dual responsibilities while getting loads of work. This is again the proof of the contrasts in domestic responsibilities between men and women in developing countries, as well as to how, as a result of this, the time of women is more constrained than that of men (see, for example, Gibbons, 2004; Hafkin \& Taggart, 2001).

\section{Networks and Associations}

Survival and sustainability in a competitive environment can be possible only by building networks. It refers not only to physical networks via meetings but also to the virtual discussions that play a major role. 80 percent of them have observed a good interpersonal communication between the members as a reason that can lead to better management of the micro enterprise. They also said that they come together and discuss their problems together to find a common solution and contact each other through e-mails and social networking sites. Participatory approach can also be a good managerial practice as all the women members have to invest in the initial stage which puts responsibility on everybody. As part of this approach they even helped other members in their work and also covered the tasks during each other's absence. All these members took training seriously which have also helped them to learn more from the experts which showed their 
dedication towards their own initiative. On their motivation, almost 90 percent of them opined that they wanted to do something for themselves and gave this project a try.

Another factor providing support for them was their public relation. They had very good relation with panchayath, municipality and corporation officials as at this stage they are able to get maximum jobs from public organisations.

One of the member said "Due to these public contacts we get our works done in panchayaths much faster than other people. We get our work done in one day while others may take three or more days."

And through these contacts which they have developed over time now they are trying to get private sector jobs, for example, two of the units have worked as hospital kiosk to enter death and birth details. Through the training they have even learned market strategies. Some of the units closed down or worked poorly due to the absence of the above explained characteristics. All the members interviewed exhibited strong commitment to stay in this field despite several hurdles faced by them which shows that commitment is the "attachment of self to the requirements of social relations" (Kanter, 1972). She further implies that salience and centrality are based on three forms of rationality: instrumental, affective, and moral (Kanter, 1972). In this light, commitment can be seen as an individual's identification with a collectivity that leads to instrumental, affective, and moral attachments that lead to investments in movement lines of activity. The "we-ness" or the "collective identity" (Hunt and Benford, 2004) developed amongst them due to their long term association can also result in such commitment.

\section{CONCLUSION}

The qualitative study done here was effective in understanding women working in these IT enterprises and adapting to the changing environment. Sen (1990) hypothesizes that women's participation in paid work tends to enhance their well-being. There are various approaches to well being. The capability approach can be applied here. Their earning's through their work can lead to increased independence and higher contribution in the economic position of their family. Physical mobility and interaction with the outside world can also lead to increased perseverance and decision making power in their household matters. As for benefits from work 92 percent said they benefitted by improving their technical skills, 94 percent opted for improvement in their communication and 50 percent found enhancement in leadership skills. These factors have greatly influenced their outlook towards themselves, self-confidence and general awareness on society. In short, ICT work gave women a reasonably good income, familiarity with modern technology, more exposure and knowledge of the working of offices. It increased their social status as a whole. These achievements spilled over to their families in the form of better education, health and other basic amenities (Pillai and Shanta, 2011). Many literatures have proved that gender empowerment and economic development go hand in hand (Elson 1995; Nussbaum 2001; Sen 2000; Prasad \& Sreedevi, 2007; Hazarika, 2011). Other dimension of these ICT enterprises has to be mentioned as they face instability in income due to the nature of work and the support withdrawn from the Kudumbashree Head Office. These can also be the reason for the shutting down of some units. Through the interviews it was identified that around 80 percent were despondent as they received low benefits and income. Literature studies, interviews and field visits on these ICT initiatives under the umbrella of Kudumbashree indicate a vast potential for the empowerment of poor women. The programme marks the opening up of opportunities in the ICT sector to poor and socially backward women with adequate organisational support. Poor women through this programme have made an entry into the lowest spectrum of IT enabled jobs (Pillai and Shanta, 2011). The declining number of these units show that the current state of training and support provided by the officials need to be reassessed. There were 236 units in the year of 2006 and now it has reduced to 63 . With the help of the officials, a stable and continuous linking of customers can be done which in turn can result in the stability and solidity of income. ICTs not only allow access to information and knowledge, they also enable and facilitate technologies that can be used to save time and money, and can improve the quality of both work and home life (Rice, 2003). Hence, ICT sector if implemented properly after need assessment and planning can lead to the empowerment of poor women to enable them to participate in the process of development.

\section{ACKNOWLEDGMENTS}

The author would like to thank Dr. Lekshmi $\vee$ Nair for her valuable insights and expertise that greatly assisted the research. This study would not be possible without the support and guidance from the Kudumabhsree officials and the members of Kudumbashree ICT enterprises.

\section{REFERENCES}

[1] Best M. Maier,"Women and Internet use in Five South Indian Villages: Challenges and Opportunities" Gender, Technology and Development, 2007,11(2), 1-4.

[2] Bhatnagar, S. and Schware, R. 2000. Information and Communication Technology in Development.

[3] Castells, Manuel. and Cardoso, Gustavo. 2005. The Network Society: From Knowledge to Policy.

[4] Castells, Manuel. 2010. The Power of Identity.

[5] Cecchini, S. 2002. Can ICT Applications Contribute to Poverty Reduction? Lessons from Rural India, Poverty Reduction Group Working Paper, World Bank,Washington, DC.

[6] Chadha. Vikram, Kapoor. Seema,"Role of the ICT in Exacerbating the Knowledge Economy of India“. World Journal of Social Sciences, 2012, 2(1), 101-103. 
[7] Dalal, Praveen. 2006. Use of ICT for Women Empowerment in India. March 16.2015 from unpan1.un.org/intradoc/groups/public/documents/APCITY/UNPAN029838.pdf

[8] Dayasindhu, N. and Pradeep, G. 2003. Nurturing a software industry in Kerala. In The Digital Challenge, S. Krishna and S. Madon (eds.), 340-358.

[9] Duncombe. Richards and Heeks. Richard. 2005. Information \& Communication Technologies (ICTs), Poverty Reduction and Micro, Small \& Medium-scale Enterprises (MSMEs). Report. Institute for Development Policy and Management.

[10] Kanter, Rosabeth. M. 1972.Commitment and Community: Communes and Utopias in Sociological Perspective.

[11] Elson, D. 1995. Male bias in the development process.

[12] Fireman, Bruce. and William, A. Gamson.1979. Utilitarian Logic in the Resource Mobilization Perspective. In The Dynamics of Social Movements, M. N. Zald and J. D. McCarthy (eds.), 8-45.

[13] Kanter, Rosabeth. M. 1972. Commitment and Community: Communes and Utopias in Sociological Perspective.

[14] Keiffer, C, "Citizen empowerment: A developmental perspective". Prevention in Human Services,1984, 3(16), 9-35.

[15] Kenny, C, "Information and communication technologies for direct poverty alleviation: costs and benefits", Development Policy Review, 2002, 20(2), 141-157.

[16] Government of Kerala, 2003 Economic Review. State Planning Board. Government of Kerala.Trivandrum, Kerala.

[17] Gurumurthy, Anita. 2004.Gender and ICTs.

[18] Haffert, N. and Taggert, N. 2001. Gender, Technology, and Developing countries: An Analytic Study.

[19] Hafkin, N. and Huyer, S. 2006. Cinderella or Cyberella? Empowering women in the Knowledge Society.

[20] Hazarika, Dhruba."Women Empowerment in India: A Brief Discussion“. International Journal of Educational Planning \& Administration, 2011, 1(3), 199-202.

[21] Heeks, R. 1999. Information and Communication Technologies, poverty and development, Development Informatics Working Paper Series, Institute for Development Policy and Management. November, 23, 2013 from http://www.sed.manchester.ac.uk/idpm/publications/wp/di/di_wp05.htm.

[22] Heeks, R.B. 1996. India's Software Industry.

[23] Hilbert, Martin,“Digital gender divide or technologically empowered women in developing countries?", Women's Studies International Forum,2011, 34(6), 479-489.

[24] Holton. E. F,"The flawed four-level evaluation model“, Human Resource Development Quarterly,1996, 7 (1), 5-25.

[25] Holton. E. F. et.al,"Toward construct validation of a transfer climate instrument". Human Resource Development Quarterly. 8 (2), 1997, 95-113.

[26] Human Development Report. 2013. Rise of the South: Human Progress in a Diverse World, United Nations Development Programme.

[27] Hunt A. Scott and Benford. D.Robert. 2004. Collective Identity, Solidarity and Commitment. March14,2015from wiki.zirve.edu.tr/sandbox/groups/economicsandadministrativesciences/wiki/0edb9/attachments/371d5/Hunt\%20and\% 20Benford.pdf

[28] Huyer S and Mitter S. 2003. ICTs, Globalization and Poverty reduction: Gender dimensions of the knowledge society. November, 20, 2013 from htttp://gab.wigsat.org/policy.html.

[29] International Telecommunication Union (ITU). 2005. Tunis agenda for the Information Society, December, 20, 2013 from http://www.itu.int/wsis/docs2/tunis/off/6rev1.html.

[30] Jorge S.N. 2002. The economics of ICT: challenges and practical strategies of ICT use for women's economic empowerment. Paper presented at UN meeting on ICTs and their Impact on and Use as an Instrument for the Advancement and Empowerment of Women, Seoul, Korea.

[31] Ministry of Rural Development. 2014. Government of India, February, 12, 2014, from www.rural.nic.in.

[32] Nath. V,"Empowerment and Governance through Information and Communication Technologies: Women's Perspectives“. International Information and Library Review, 2001,33, 317-339.

[33] Nussbaum, C. Martha. 2001. Women and Human Development - The Capabilities Approach.

[34] Pillai. Mohanan and Shanta. N,“ICT and Employment Promotion among Poor Women: How can we make it happen?Some Reflections on Kerala Experience“. Indian Journal of Gender Studies, 2011.

[35] Prasad, P. N and Sreedevi, V,“Economic Empowerment of Women through Information Technology: A Case Study from an Indian State“. Journal of International Women's Studies, 2007, 8(4), 107-120.

[36] Martin. M. Lynn and Wright. Tiu Lenn, "No gender in cyberspace? Empowering entrepreneurship and innovation in female-run ICT small firms". International Journal of Entrepreneurial Behaviour \& Research,2005, 11(5), 162-178.

[37] Puchner. L. D,"Women and Literacy in Rural Mali: A Study of the Socio-Economic impact of participating in literacy programs in four Villages“, International Journal of Educational Development, 2003, 23(4), 439-458. 


\section{ISSN 2321-1091}

[38] Rice. F. Mitchell, "Information and Communication Technologies and the Global Digital Divide - Technology Transfer, Development, and Least Developing Countries", Comparative Technology Transfer and Society, 2003, 1(1), 75.

[39] Sen. A. 2000. Development as Freedom.

[40] Shrivastav and Ekata. Anand. Kumar,"ICT Penetration and Cybercrime in India: A Review“. International Journal of Advanced Research in Computer Science and Software Engineering, 2013, 3(7), 414-416.

[41] Singall. A. and Rogers E. 2001. India's Information Revolution: From Bullock Carts to Cyber Marts.

[42] United Nations Conference on Trade and Development (UNCTAD). 2002. E-commerce and development. New York and Geneva: United Nations.

[43] Wajcman. Judy,"Addressing Technological Change: The Challenge to Social Theory“. Current Sociology, 2002, 50(3), 347-363.

[44] Walby, S. 2000. The restructuring of the gendered political economy: transformations in women's employment, InTowards a Gendered Political Economy, J. Cook, J. Roberts and G. Waylen, 165-188.

[45] Wendling. Amy. E .2009. Karl Marx on Technology and Alienation.

[46] Whitmore, E. 1988. Empowerment and the process of inquiry. A paper presented at the annual meeting of the Canadian Association of Schools of Social Work, Windsor,Ontario.

\section{Author' biography with Photo \\ Rashmi M}

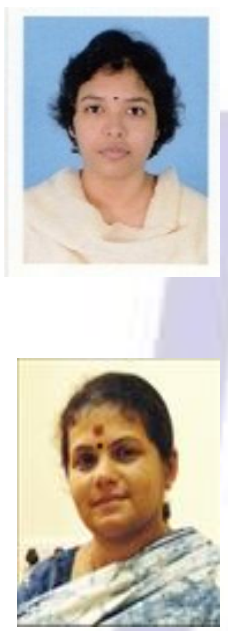

She is currently pursuing her PhD from Indian Institute of Space Science and Technology, Trivandrum , Kerala. Her topic of research is "Reaching the Unreached: A Prescriptive Study on the Use of Government ICT Programmes amongst Women in Kerala“. Her areas of interest include gender and technology, science, technology and society.

\section{Dr. Lekshmi V Nair}

She is an associate professor in Department of Humanities, Indian Institute of Space Science and Technology, Trivandrum, Kerala. Her major area of research includes Gerontology, Social Research, Gender Studies, PLA, Science, Technology and Society, Tribal Studies. 